\title{
Modification in Bi-Ag Lead-Free Solder-Bearing Alloying Elements
}

\author{
Rizk Mostafa Shalaby ${ }^{1}$, Musaeed allzeleh ${ }^{1,2}$, Mustafa Kamal ${ }^{1}$ \\ ${ }^{1}$ Metal Physics Lab., Physics Department, Faculty of Science, Mansoura University, Mansoura, Egypt, B. O. Pox: \\ 35516 \\ ${ }^{2}$ On leave, M.Sc student, Ministry of Higher Education, Yemen. \\ ${ }^{1}$ rizk2002@mans.edu.eg, ${ }^{2}$ Musaeed1982@gmail.com
}

\begin{abstract}
The development of lead-free solder has an urgent task for material scientist due to health and environmental concerns over the lead content of traditional solders. The objective of this study is to examine Bi-Ag-rare earth (RE) element considered as one of the more attractive lead-free solders since it can easily replace $\mathrm{Sn}-\mathrm{Pb}$ eutectic alloy with increasing soldering temperature while causes for high-temperature applications. In order to enhance the soldering properties of Bi-Ag alloys, a trace eare earth (RE) element of Ho added into $\mathrm{Bi}-\mathrm{Ag}$ alloys. The results indicated that the addition of RE led to the refining of coarse $\mathrm{Bi}-\mathrm{Ag}$ grains, in the microstructure. The tensile strength, $\mathrm{Hv}$ and creep resistance increased with a decrease in melting point and electrical resistance. This paper brief the influences of rare earth alloying element and rapid solidification on both of the microstructure, intermetallic compounds, creep resistance, melting behavior, electrical resistance and mechanical behavior.
\end{abstract}

Keywords: Rapid solidification; Bi-Ag-RE lead free solder; microstructure; mechanical behavior

Language: English

Date of Submission: 10-06-2018

Date of Acceptance: 20-06-2018

Date of Publication: $30-06-2018$

DOI: 10.24297/jap.v14i2.7471

ISSN: $2347-3487$

Volume: 14 Issue: 2

Journal: Journal of Advances in Physics

Website: https://cirworld.com

This work is licensed under a Creative Commons Attribution 4.0 International License. 


\section{Introduction}

The solder alloys are one of the basic technologies which used in the electronic packaging process. At present, The solder alloys have become indispensable in the production of electronic devices and that used in many fields, such as the automotive industry, aircraft, space satellite, oil/gas well explorations, automobile circuit boards, etc [1-3]. But due to the toxicity of lead, which greatest risk the environment and human health $[4,5]$. European Union, Japan, and other countries have banned the use lead solder in production Electronic devices. As an outcome, it became necessary to produce and development of lead-free solder [6-8]. The new lead-free solder alloys, need to meet a variety of characteristics, such as, have the melting point acceptable to withstand the operating temperature and also to avoid thermal damage to the assembly being soldered, exhibit sufficient electrical conductivity, possess adequate mechanical properties, strength; toughness; and creep resistance, available ( sufficient quantities of candidate metals to meet the current and further requirements), and finally, have acceptable cost. All of the above mentioned physical properties are controlled through the structural changes of the solder alloys. such as defects, lattice strain, particle size, grain boundary, and atoms arrangements. Hence, the importance of techniques comes from its potential to control the structural formation. In rapid solidification processing (RSP) from melt is occurring rapid extraction of thermal energy, this leads to produce manufactured material of extraordinary and has unique properties, due to reduced levels of segregation, increase the solid solubility of alloying components, decrease in the grain size, uniform concentration of Impurities in matrix, IMC formation, and in some states the figuration of metastable crystalline and amorphous phases. In our laboratory (metal Lab-Mansoura University- Egypt) was achieved rapid solidification processing of solder alloys by chill block melt spinning technique at a high cooling rate $=10^{6} \mathrm{k} / \mathrm{s}$ ) producing ribbons with superior microstructure, mechanical and thermal properties [9-15]. Till now, few alternative alloys have been proposed for lead-free solder alloys, Bi-Ag alloy is one of these alternatives [16-18]. Bismuth is a nontoxic metal that has a shear modulus $(\mathrm{G}=12 \mathrm{GPa})$ and a melting point $\left(271^{\circ} \mathrm{C}\right)$ closest to that of the $\mathrm{Pb}-5 \mathrm{Sn}$ alloy $\left(\mathrm{G}=9.34 \mathrm{GPa}\right.$, melting point $\left.=305-315^{\circ} \mathrm{C}\right)$. As also, the studies have indicated that adding small amounts of $\mathrm{Ag}$ can refine the microstructure of Sn-Bi alloys [19]. So, the presence of silver particles in the microstructure should be led to resulted in bismuth-silver alloys being mechanically stronger [20]. But, mechanical and electrical properties of Bi-Ag alloys must be improved to become commercially viable lead-free solder. The rare earth (RE) elements are surface-active elements. Which means that a minute amount of RE elements may greatly enhance the properties of metals. Which causes improving the high temperature performance of solder alloys [21-25]. To our knowledge, ternary $\mathrm{Bi}_{100-x} \mathrm{Ag}_{0.5} \mathrm{Ho}_{\mathrm{x}}$ ( $\mathrm{x}=0$ up to 0.5 wt.\%) system has not been experimentally investigated so far. So, this study aims to improve the mechanical, thermal and electrical properties of the Bi-0.5 Ag solder alloy, through adding small amount of rare earth element $(\mathrm{Ho})$ by a method of rapid solidification from melt using melt-spinning technique.

\section{Experimental procedures}

\subsection{Specimens preparation}

The experimental techniques utilized have been described in details [26,27] and will be explained herein briefly. In this study, Seven light weight alloys of compositions Bi pure and Bi-Ag0.5-Hox (where $x=0,0.1,0.2$, $0.3,0.4$, and $0.5 \mathrm{Wt}$. \%), were prepared from pure $\mathrm{Bi}, \mathrm{Ag}$ and $\mathrm{Ho}$ (purity $>99.9 \%$ ). The weighted metals for each composition were melted in a porcelain crucible using an electric furnace at about $450{ }^{\circ} \mathrm{C}$ for $30 \mathrm{~min}$. With the help of a graphite rod, the Silver and Holmium were pushed down into the molten solder. After 20 minutes from heating of the alloys become in the molten state, then are mechanically stirred by a graphite rod to increase the homogenization and put them back in the furnace for 20 minutes. Then rapidly solidified from the molten state (from melt) by squirting a stream of molten alloy on a single copper roller ( type meltspinning technique). The rotation speed of the surface of the roller used in this work was about $2900 \mathrm{rpm}$ ( the linear velocity corresponding is approximately $31.5 \mathrm{~m} / \mathrm{s}$ ). The resulting alloys had long ribbons form, have of thickness ranging from 60 to $80 \mu \mathrm{m}$. 


\subsection{Sample characterizationa}

The structural analysis of rapidly solidifed melt-spun solders was examined by X-ray diffraction (XRD) taken withCuKa radiation. The microstructure scan was carried out on a scanning electron microscope of kind JSM-6510 LV JEOL (Japan), operating at (30 kV) resolution in high vacuum mode, and $3.0 \mathrm{~nm}$. The hardness $(\mathrm{Hv})$ and the creep indentation was examined by a digital Vickers microhardness tester (Kind-FM-7- Japan), applying a load of $10 \mathrm{gf}$ (gram-force), dwell time of load (5,20,40,60,80,90 seconds) [10]. Differential scanning calorimetry analysis (DSC) was carried out in a Shimadzu DT-50 with a heating rate $10 \mathrm{~K} / \mathrm{min}$. Measurement of electrical properties was made resistivity utilizing a Micro-ohmmeter. The temperature was measured with an accuracy of $\pm 0.01 \mathrm{k}$ utilizing a calibrated digital thermometer.

\section{Results and discussion}

\subsection{Structure}

Fig. 1 shows the $\mathrm{X}$-ray diffraction patterns of melt-spun solder alloys for compositions of Bi pure and $\mathrm{Bi}_{100-\mathrm{x}}-\mathrm{Ag}_{0.5}-\mathrm{Ho}_{\mathrm{x}}$ (where $\mathrm{x}=0.1,0.2,0.3,0.4$, and $0.5 \mathrm{wt} . \%$ ). As shown in Fig (b g) presence of sharp peaks and intensity related to structure of $\alpha-\mathrm{Bi}$ (Hex.) phase and intermetallic compound IMC (cubic) $\mathrm{Ag}_{99.5} \mathrm{Bi}_{0.5}$ at $2 \theta=$ $64.496^{\circ}$. The presence of IMC indicates the dissolution of $\mathrm{Ag}$ atoms into the molten Bi-matrix. where found that $\mathrm{Ag}$ atoms tend to interact much more strongly with $\mathrm{Bi}$ to form IMC such as $\mathrm{Ag}_{99.5} \mathrm{Bi}_{0.5}$. There is not any peaks indicate to Ho in Fig.1. This is means that the small amount of Ho addition to Bi-0.5Ag not cause the formation of any new phases in the microstructure, but it is led to refinement the as-cast microstructure. The details of the X-ray diffraction analysis summarized in the Table1. The particle size of $\mathrm{Bi}$ and $\mathrm{Ag}_{0.5} \mathrm{Bi}_{99.5} \mathrm{IMC}$ decreased from $395.87 \AA$ and $367.12 \AA$ to $298.993 \AA$ and $280.709 \AA$ respectively at 0.5 wt.\% Ho. This led to reasonable enhancement of the electrical and mechanical properties. The cell volume changed very little after addition $\mathrm{Ho}$ and the number of atoms in the unit cell decreased, which can be attributed to the atomic radius of $\mathrm{Ho}\left(174.3 \times 10^{-3} \mathrm{~nm}\right)$ which is higher than that of $\mathrm{Bi}\left(154.5 \times 10^{-3} \mathrm{~nm}\right)$ and $\mathrm{Ag}\left(144.5 \times 10^{-3} \mathrm{~nm}\right)$, i.e may be due to the atomic spacing increases.

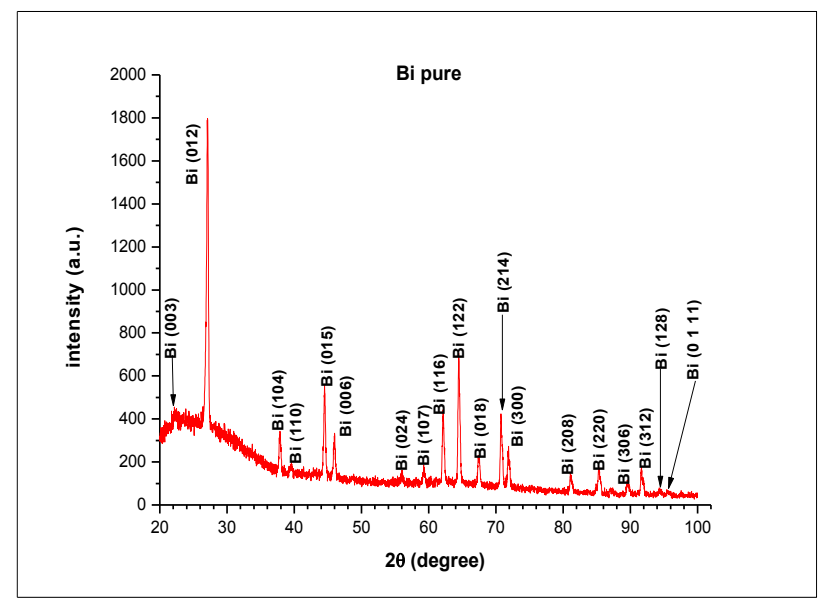

(a)

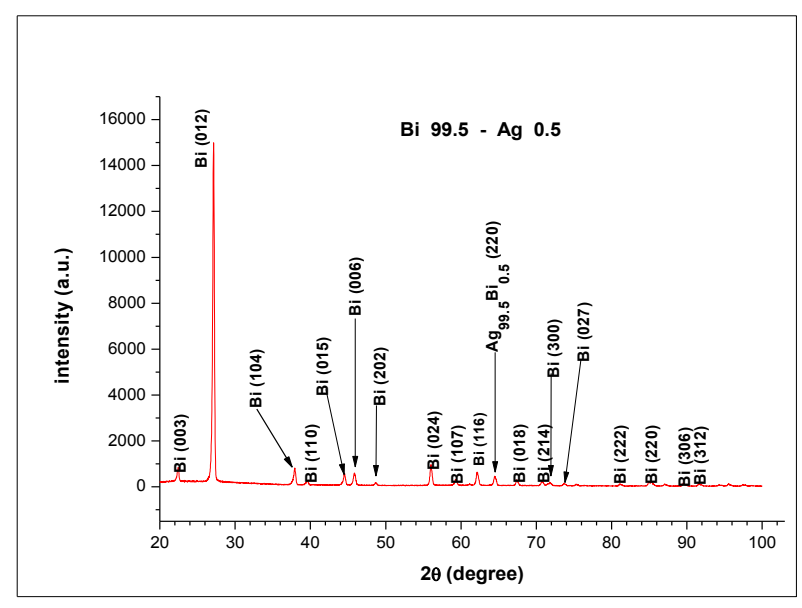

(b) 


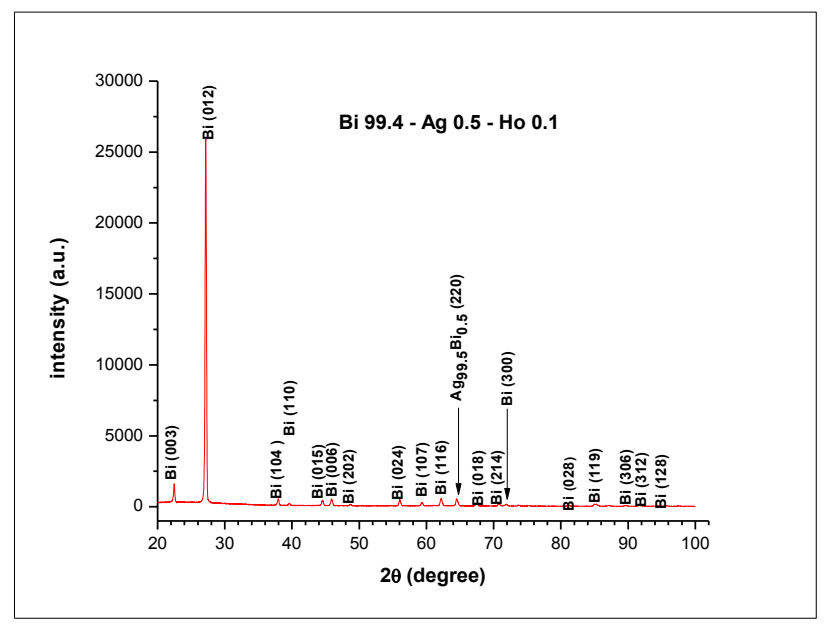

(c)

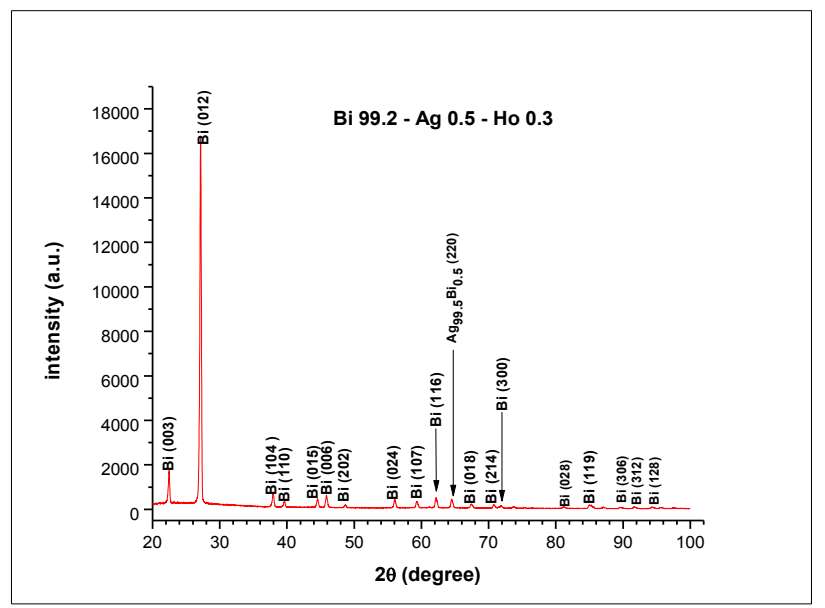

(e)

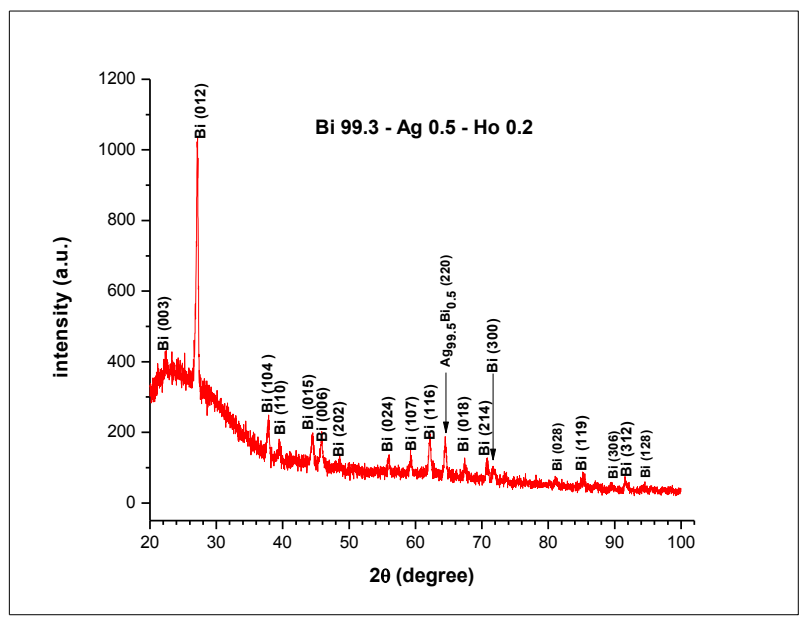

(d)

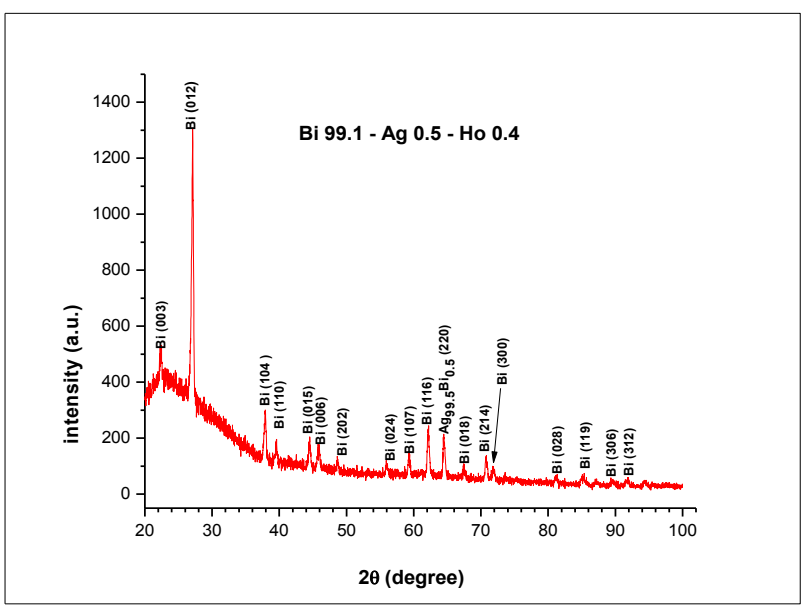

(f)

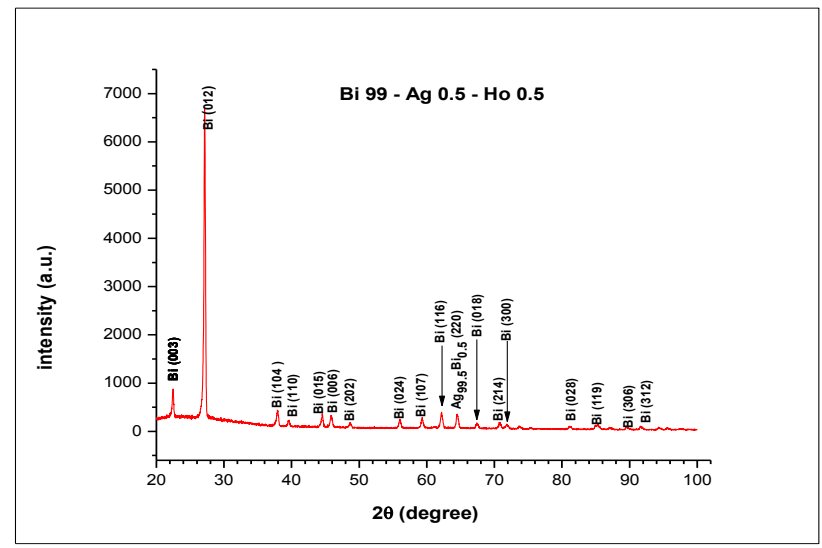

(g)

Fig.1. X-ray diffraction patterns of $\mathrm{Bi}_{100-\mathrm{x}}-\mathrm{Ag}_{0.5}-\mathrm{Ho}_{\mathrm{x}}(\mathrm{x}=0,0.1,0.2,0.3,0.4$, and 0.5$)$ solder alloys. 
Table 1: The XRD details of $\mathrm{Bi}_{100-x}-\mathrm{Ag}_{0.5}-\mathrm{Ho}_{\mathrm{x}}(\mathrm{x}=0,0.1,0.2,0.3,0.4$, and 0.5$)$ lead free solder.

\begin{tabular}{|c|c|c|c|c|c|c|c|c|}
\hline \multirow{2}{*}{ Solder } & \multicolumn{3}{|c|}{ Lattice parameters } & \multirow{2}{*}{$\begin{array}{l}\text { Unit-cell } \\
\text { volume } \\
(\AA)^{3}\end{array}$} & \multirow{2}{*}{$\begin{array}{l}\text { Particle } \\
\text { size } \\
(\AA)\end{array}$} & \multirow{2}{*}{$\begin{array}{l}\text { lattice } \\
\text { distortion } \\
\times 10^{-3}\end{array}$} & \multirow{2}{*}{$\begin{array}{l}\text { Phases } \\
\text { designation }\end{array}$} & \multirow{2}{*}{ Crystal system } \\
\hline & a $(\AA)$ & c $(\AA)$ & $c / a$ & & & & & \\
\hline $\mathrm{Bi}$ & 4.5495 & 11.6337 & 2.5572 & 208.5316 & 385.203 & 1.367 & $\mathrm{Bi}$ & Rhomb. (hex). \\
\hline \multirow{2}{*}{ Bi_Ag 0.5} & 4.6759 & 11.234 & 2.4026 & 212.723 & 395.87 & 1.153 & $\mathrm{Bi}$ & Rhomb. (hex). \\
\hline & 4.089 & & & 68.366 & 367.12 & 1.006 & $\mathrm{Ag}_{99.5} \mathrm{Bi}_{0.5}$ & Cubic. \\
\hline \multirow{2}{*}{$\mathrm{Bi}-\mathrm{Ag}_{0.5}-\mathrm{Ho}_{0.1}$} & 4.551 & 11.915 & 2.618 & 213.732 & 396.365 & 1.164 & $\mathrm{Bi}$ & Rhomb. (hex). \\
\hline & 4.088 & & & 68.335 & 381.523 & 0.542 & $\mathrm{Ag}_{99.5} \mathrm{Bi}_{0.5}$ & Cubic. \\
\hline \multirow{2}{*}{$\mathrm{Bi}-\mathrm{Ag}_{0.5}-\mathrm{Ho}_{0.2}$} & 4.55 & 11.865 & 2.6077 & 212.708 & 341.214 & 1.294 & $\mathrm{Bi}$ & Rhomb. (hex). \\
\hline & 4.086 & & & 68.23 & 397.682 & .928 & $\mathrm{Ag}_{99.5} \mathrm{Bi}_{0.5}$ & Cubic. \\
\hline \multirow{2}{*}{$\mathrm{Bi}-\mathrm{Ag}_{0.5}-\mathrm{Ho}_{0.3}$} & 4.551 & 11.872 & 2.609 & 212.965 & 340.31 & 1.326 & $\mathrm{Bi}$ & Rhomb. (hex). \\
\hline & 4.089 & & & 68.364 & 397.581 & 0.929 & $\mathrm{Ag}_{99.5} \mathrm{Bi}_{0.5}$ & Cubic. \\
\hline \multirow{2}{*}{$\mathrm{Bi}-\mathrm{Ag}_{0.5}-\mathrm{Ho}_{0.4}$} & 4.548 & 11.932 & 2.623 & 213.788 & 275.344 & 1.806 & $\mathrm{Bi}$ & Rhomb.(hex). \\
\hline & 4.86 & & & 68.201 & 340.974 & 1.083 & $\mathrm{Ag}_{99.5} \mathrm{Bssi}_{0.5}$ & Cubic. \\
\hline \multirow{2}{*}{$\mathrm{Bi}-\mathrm{Ag}_{0.5}-\mathrm{Ho}_{0.5}$} & 4.553 & 11.848 & 2.602 & 212.651 & 298.993 & 1.497 & $\mathrm{Bi}$ & Rhomb.(hex). \\
\hline & 4.087 & & & 68.273 & 280.709 & 1.315 & $\mathrm{Ag}_{99.5} \mathrm{Bi}_{0.5}$ & Cubic. \\
\hline
\end{tabular}

Table 2: cell volume, density number of atoms per unit cell of $\mathrm{Bi}_{100-\mathrm{x}}-\mathrm{Ag}_{0.5}-\mathrm{Ho}_{\mathrm{x}}(\mathrm{x}=0,0.1,0.2,0.3,0.4$, and 0.5$)$ lead free solder.

\begin{tabular}{llll}
\hline Solder & $\begin{array}{l}\text { Cell volume } \\
(\AA) 3\end{array}$ & $\begin{array}{l}\text { Density } \\
\mathrm{g} / \mathrm{cm} 3\end{array}$ & $\begin{array}{l}\text { (n) number of } \\
\text { atoms in a } \\
\text { unit cell }\end{array}$ \\
\hline Bi pure & 208 & 9.246 & 5.56 \\
\hline $\mathrm{Bi}-\mathrm{Ag}_{0.5}$ & 212.723 & 9.905 & 6.088 \\
\hline $\mathrm{Bi}-\mathrm{Ag}_{0.5}-\mathrm{Ho}_{0.1}$ & 213.732 & 9.547 & 5.897 \\
\hline $\mathrm{Bi}_{-} \mathrm{Ag}_{0.5}-\mathrm{Ho}_{0.2}$ & 212.708 & 9.008 & 5.54 \\
\hline $\mathrm{Bi}-\mathrm{Ag}_{0.5}-\mathrm{Ho}_{0.3}$ & 212.965 & 8.611 & 5.304 \\
\hline $\mathrm{Bi}-\mathrm{Ag}_{0.5}-\mathrm{Ho}_{0.4}$ & 213.788 & 9.261 & 5.723 \\
\hline $\mathrm{Bi}-\mathrm{Ag}_{0.5}-\mathrm{Ho}_{0.5}$ & 212.651 & 8.777 & 5.397 \\
\hline
\end{tabular}




\subsection{Microstructure analysis}

Fig. 2 display the scanning electron microscope of all prepared specimens. The large black area represents the Bi phase and small bright regions as IMC $\left(\mathrm{Ag}_{0.5} \mathrm{Bi}_{99.5}\right)$ and $\mathrm{Ho}$, the particle size of IMC is slightly larger than Ho. Addition Ho more 0.2 wt.\% in $\mathrm{Bi}_{99.5}-\mathrm{Ag}_{0.5}$ create a more uniform distribution and much finer grain size of IMC as shown in Fig $2(f, g, h)$. These observations are in good agreement with $\mathrm{X}$-ray calculations.

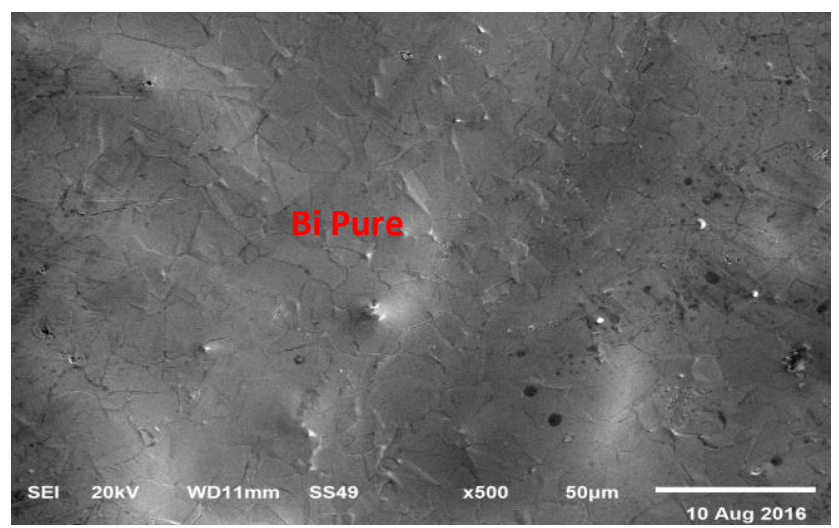

A (Bi pure)

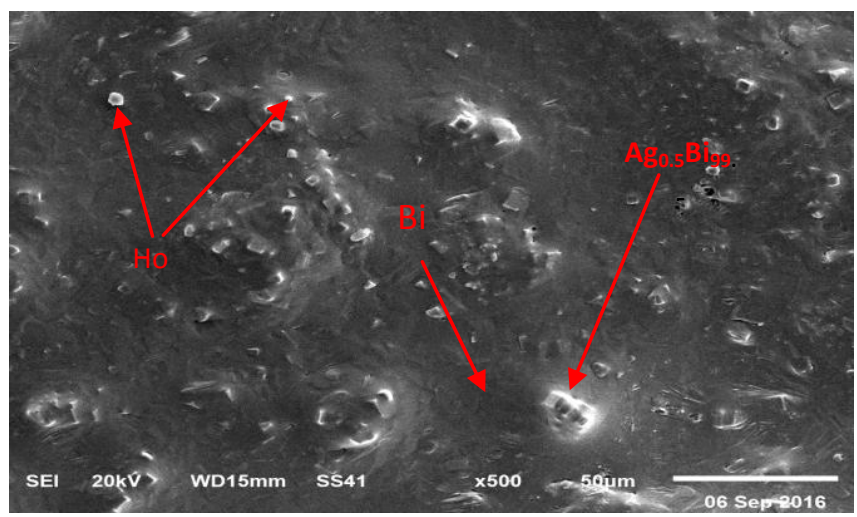

c $\left(\mathrm{Bi}_{99.4-} \mathrm{Ag}_{0.5}-\mathrm{Ho}_{0.1}\right)$

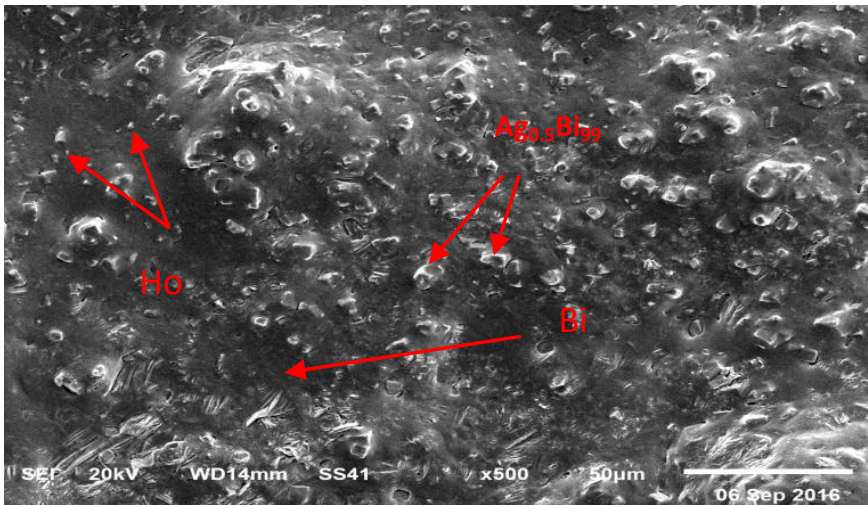

$f\left(\mathrm{Bi}_{99.2}-\mathrm{Ag}_{0.5}-\mathrm{Ho}_{0.3}\right)$

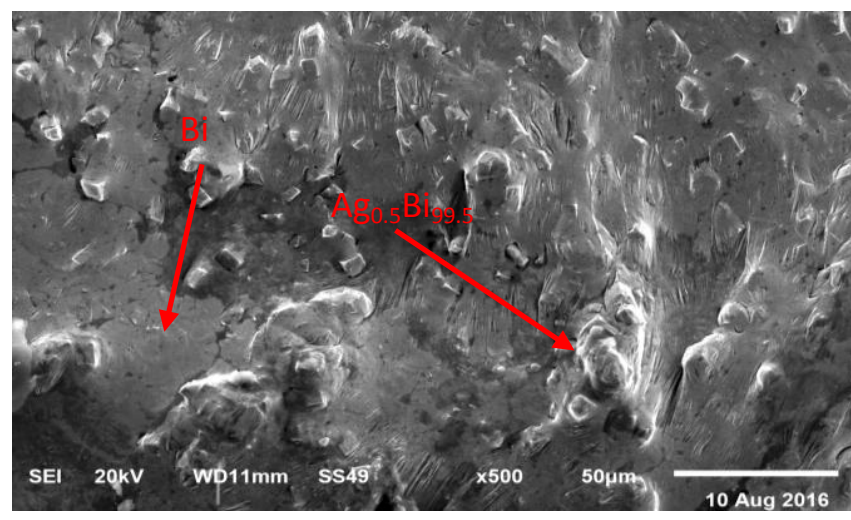

b $\left(\mathrm{Bi}_{99.5}-\mathrm{Ag}_{0.5}\right)$

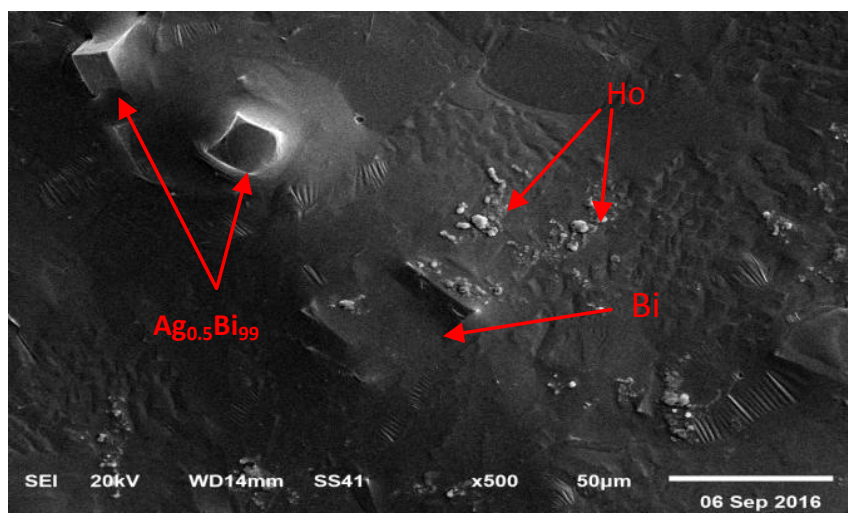

d $\left(\mathrm{Bi}_{99.3}-\mathrm{Ag}_{0.5-} \mathrm{Ho}_{0.2}\right)$

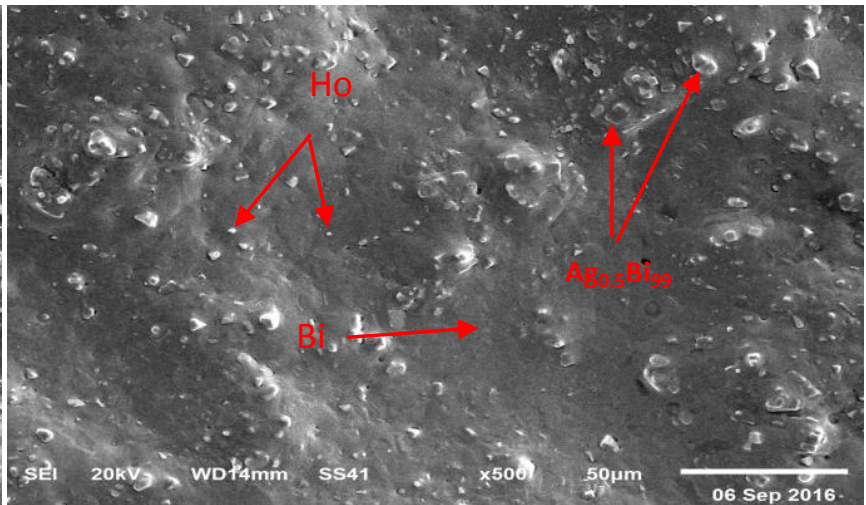

$\mathrm{g}\left(\mathrm{Bi}_{99.1}-\mathrm{Ag}_{0.5}-\mathrm{Ho}_{0.4}\right)$ 


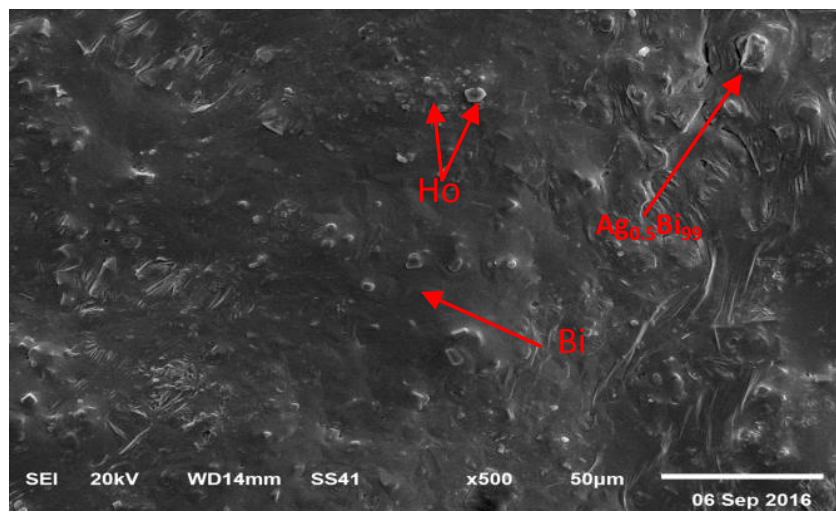

g $\left(\mathrm{Bi}_{99}-\mathrm{Ag}_{0.5-}-\mathrm{Ho}_{0.5}\right)$

Fig.2. SEM microstructure of melt spun of $\mathrm{Bi}_{100-\mathrm{x}}-\mathrm{Ag}_{0.5}-\mathrm{Ho}_{\mathrm{x}}(\mathrm{x}=0,0.1,3,0.4$, and 0.5$)$ lead free solder.

\subsection{Melting behavior}

The most challenge in $\mathrm{Pb}$-free solders manufacturing is the high temperature, where some researchers interested to minimize a gap between the thermal properties of electronic devices and the melting point of the solder alloy. The melting point of the solder must be high so that it is difficult to reflowed in the electronic packaging process and causes thermal damage to the polymer substrate. Fig. 3 displays DSC curves of rapidly solidified of all solder alloys in the temperature range from room temperature to $450{ }^{\circ} \mathrm{C}$ with a heating rate 10 ${ }^{\circ} \mathrm{C} / \mathrm{min}$, one endothermic peak was observed, its location congruous to the melting point. From this figure, the melting point $\left(T_{m}\right)$, solidus temperature $\left(T_{s}\right)$, liquidus temperature $\left(T_{1}\right)$, pasty range and other thermal parameters ( enthalpy $\Delta \mathrm{H}$, and specific heat $C_{p}$ ) of alloys are identified and then listed in Table 3 . The melting point decreased little after addition $\mathrm{Ho}$, may be due to a low particle size of Bi phase and $\mathrm{Ag}_{0.5} \mathrm{Bi}_{99.5}$. According to Table 3, the pasty range of $\mathrm{Bi}_{99} \mathrm{Ag}_{0.5} \mathrm{Ho}_{0.5}$ is less valuable, due to increase concentration of $\mathrm{Ho}$ and rapid solidification. This property is considered very important for solder, due to creating strong bonds during soldering operations when the pasty range is narrow. It's indicated that the specific heat (Cp) is an important factor for the solder material as intrinsic property. The specific heat increased with addition Ho. The height of $C_{p}$ means height energy needed for temperature changing [28].

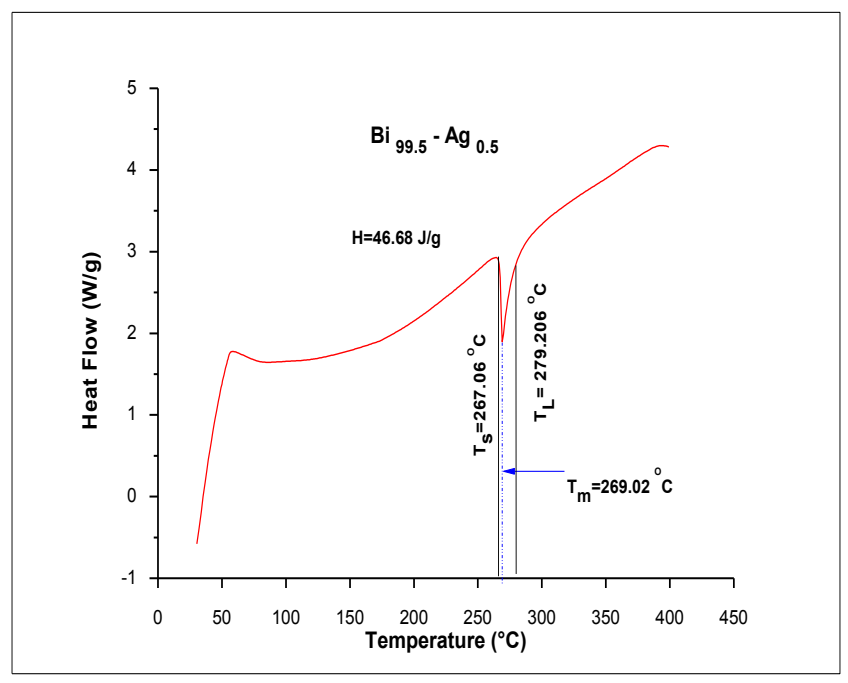

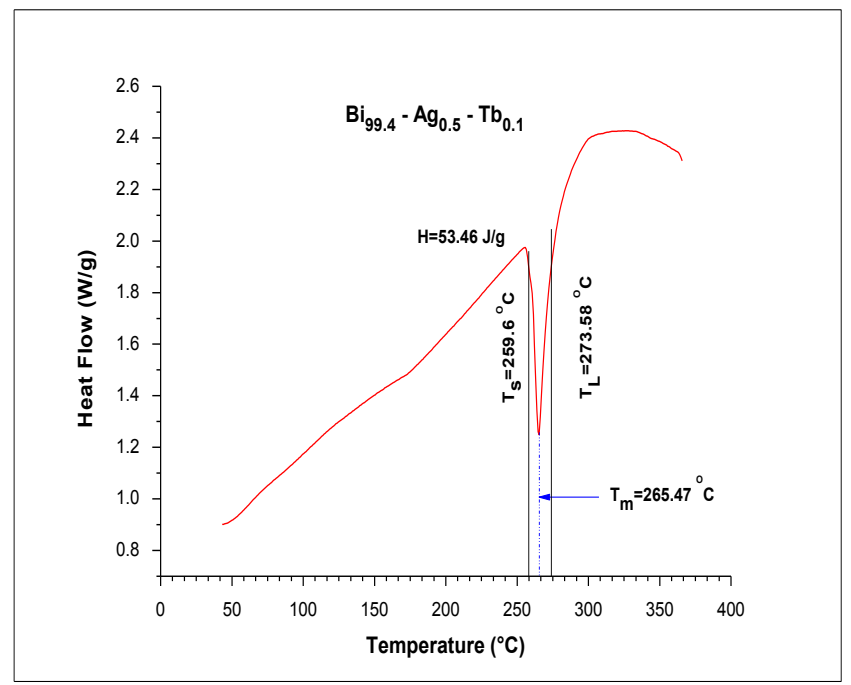




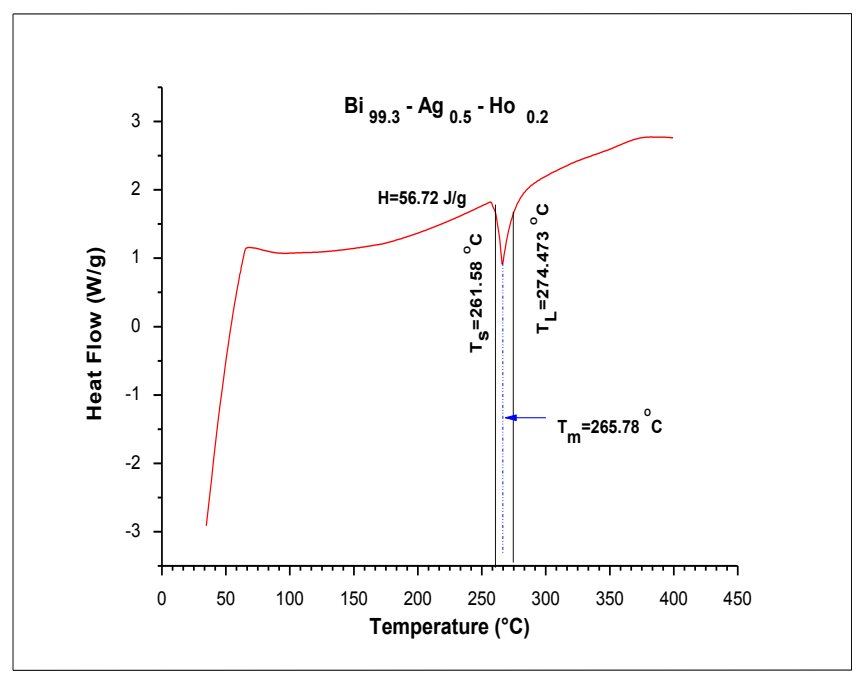

C

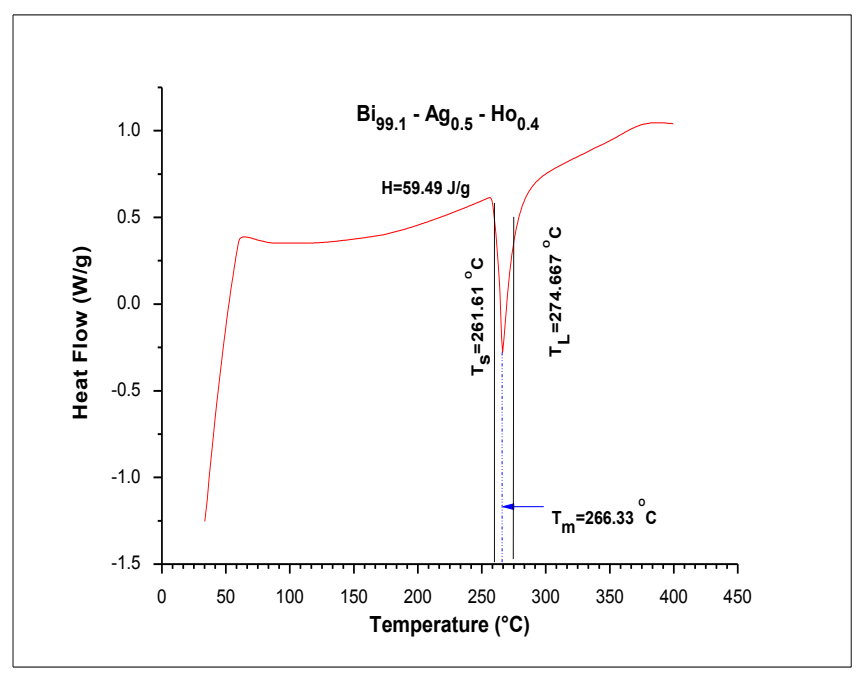

e

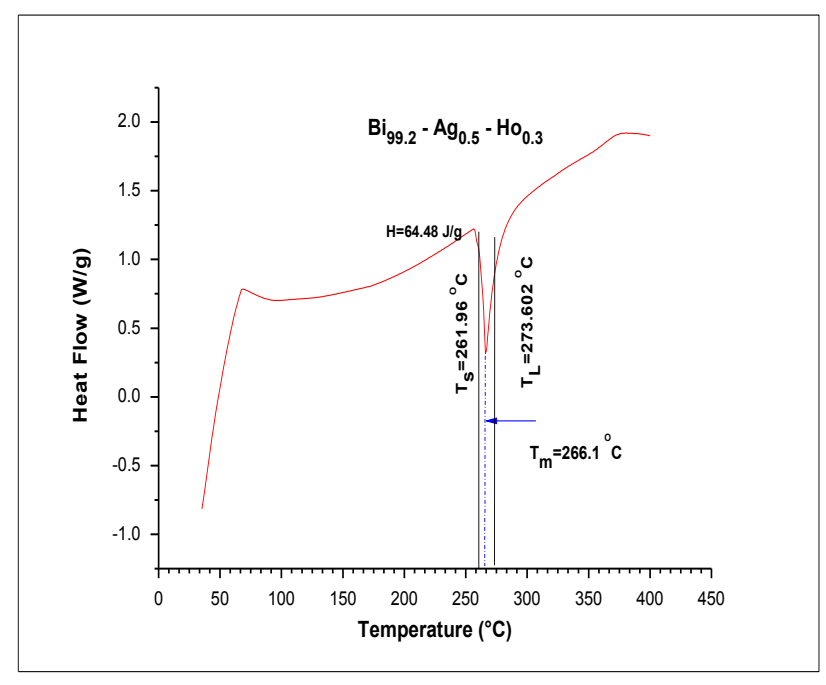

d

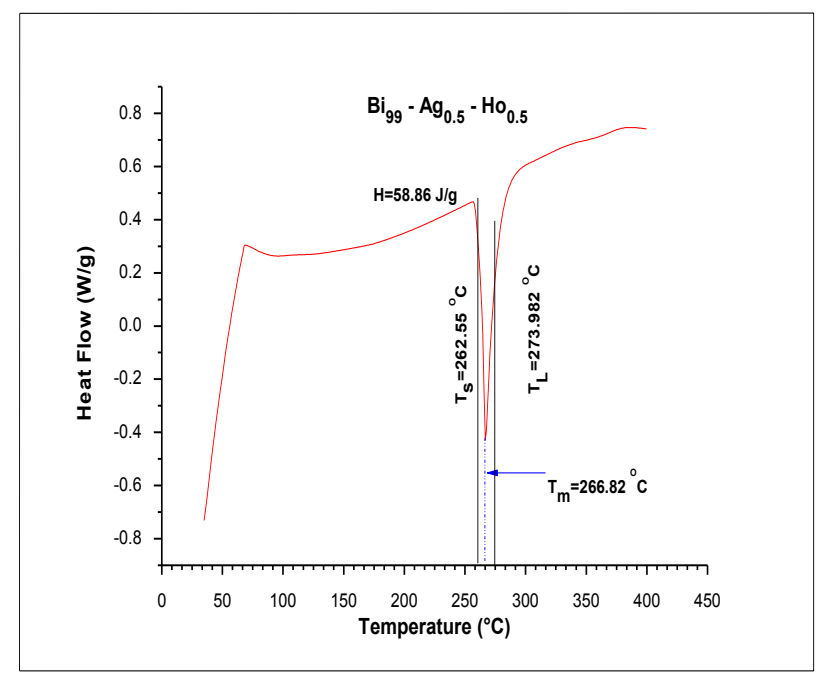

f

Fig.3. Differential scanning calorimetry of melt-spun $\mathrm{Bi}_{100-\mathrm{x}}-\mathrm{Ag}_{0.5}-\mathrm{Ho}_{\mathrm{x}}(\mathrm{x}=0,0.1,0,2.0,3,0,4$ and 0.5$)$ lead free solder alloys. 
Table 3. Thermal analysis of all prepared $\mathrm{Bi}_{100-x}-\mathrm{Ag}_{0.5}-\mathrm{Ho}_{\mathrm{x}}(\mathrm{x}=0,0.1,0,2.0,3,0,4$ and 0.5$)$ melt-spun alloys.

\begin{tabular}{|c|c|c|c|c|c|c|}
\hline System wt. \% & $\mathrm{T}_{\mathrm{m}}\left({ }^{\circ} \mathrm{C}\right)$ & $\mathrm{T}_{\mathrm{s}}\left({ }^{\circ} \mathrm{C}\right)$ & $\mathrm{T}_{1}\left({ }^{\circ} \mathrm{C}\right)$ & $\begin{array}{l}\text { Pasty } \\
\text { range }\left({ }^{\circ} \mathrm{C}\right)\end{array}$ & $\begin{array}{l}\text { Enthalpy } \\
\Delta \mathrm{H}(\mathrm{j} / \mathrm{g})\end{array}$ & $\begin{array}{l}\text { Specific } \\
\text { heat Cp } \\
(j / g . k)\end{array}$ \\
\hline $\mathrm{Bi}^{-\mathrm{Ag}_{0.5}}$ & 269.02 & 267.06 & 279.206 & 12.146 & 46.68 & 3.84 \\
\hline $\mathrm{Bi}-\mathrm{Ag}_{0.5}-\mathrm{Ho}_{0.1}$ & 265.47 & 259.6 & 273.58 & 13.98 & 53.46 & 3.82 \\
\hline $\mathrm{Bi}-\mathrm{Ag}_{0.5}-\mathrm{Ho}_{0.2}$ & 265.78 & 261.58 & 274.473 & 12.893 & 56.72 & 4.39 \\
\hline $\mathrm{Bi}-\mathrm{Ag}_{0.5}-\mathrm{Ho}_{0.3}$ & 266.1 & 261.96 & 273.602 & 11.642 & 64.48 & 5.54 \\
\hline $\mathrm{Bi}-\mathrm{Ag}_{0.5}-\mathrm{Ho}_{0.4}$ & 266.33 & 261.61 & 274.667 & 13.057 & 59.49 & 4.56 \\
\hline $\mathrm{Bi}-\mathrm{Ag}_{0.5}-\mathrm{Ho}_{0.5}$ & 266.82 & 262.55 & 273.982 & 11.432 & 58.86 & 5.15 \\
\hline
\end{tabular}

\subsection{Mechanical properties}

\subsubsection{Influence of Ho addition on Young's modulus}

Young's modulus (E) is one of the most important mechanical features that reflect strongly the interaction and the bonding nature among constituent atoms [29]. So the $E$ one of the most structure incentives of the mechanical properties due to cannot be a change in these forces without changing the basic nature of the material. Therefore, it can be slightly influenced by alloying additions. The dynamic resonance method has a definite advantage over the static method of measuring elastic moduli because the lowlevel alternating stress does not permit inflate inelastic processes, example elastic hysteresis or creep [30]. The elastic moduli obtained with the resonance method give information about elastic compliances along the long axis of the melt-spun ribbons. In an elastically isotropic body such as a well prepared polycrystalline quenched ribbons, the elastic moduli are identical in any direction. Elastic moduli can be obtained from frequency fo, at which peak damping occurs, according to [31]:

$$
E=38.32 \frac{\rho L^{4} f_{o}^{2}}{t^{2}}
$$

Where $\rho, L$, and $t$ are density, length, and thickness respectively for the specimens. The resonance curves for all of the prepared solder alloys in this work and that was measured at $27^{\circ} \mathrm{C}$ is shown in Fig. 3. The elastic constants for these alloys were calculated as in Table 4. It is noted that by the addition " 0.5 wt\%" of Ag in $\mathrm{Bi}_{\text {, }}$ the increase in elastic modulus is about $57 \%$. This is may be due to formation IMC $\left(\mathrm{Ag}_{0.5} \mathrm{Bi}_{99.5}\right)$ according to XRD analysis. It is noted in this study that, by the addition of $0.2 \mathrm{wt} \% \mathrm{Ho}$, the elastic modulus slightly increased, while the addition of $0.5 \mathrm{wt} \%$ Ho produces increasing by about $33 \%$ from the value of $\mathrm{Bi}-0.5 \mathrm{Ag}$ alloy, and also the addition $0.5 \mathrm{wt} . \%$ Ho resulted in a great increase in the thermal diffusivity, whereas the internal friction $\left(Q^{-1}\right)$ is slightly decreased. from XRD analysis is observed the absence of any IMC after the addition of Ho on the binary alloy (Bi-Ag). However, the addition of small amounts of holmium resulted in an increase of Young's modulus. This is may be attributed to decrease the particle size according to X-ray analysis, may be the homogeneous distribution of IMC and Ho particles in Bi-matrix as appeared in the SEM images, and may be arise from prevent atomic motion along dislocations and /or grain boundaries. 


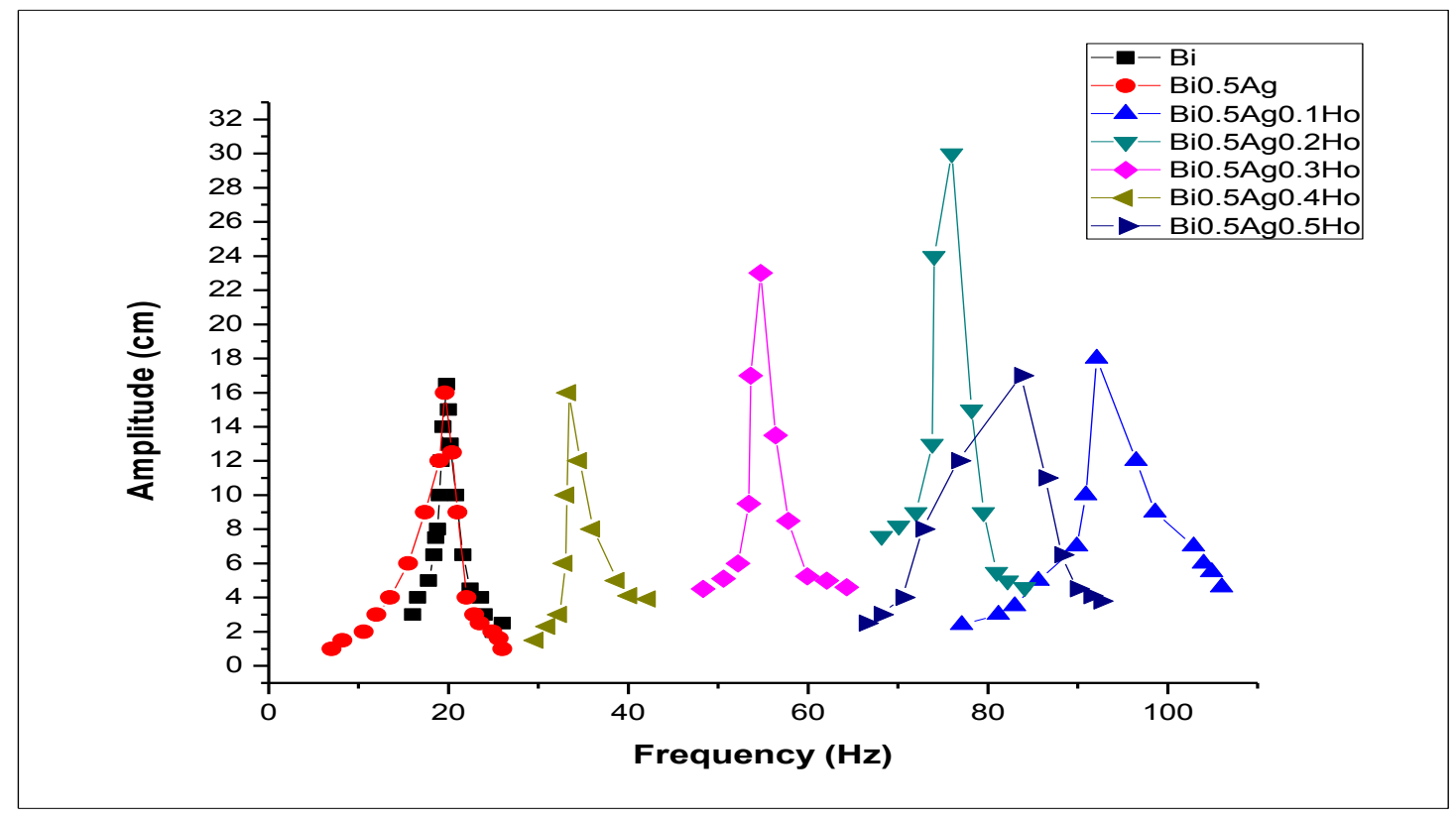

Fig.4. Resonance curves for melt spun $\mathrm{Bi}-\mathrm{Ag}-\mathrm{RE} \mathrm{Pb}$-free solder alloys with $\mathrm{Ho}$ additions.

Table 4. Young's modulus, internal friction, and thermal diffusivity of $\mathrm{Bi}_{100-\mathrm{x}}-\mathrm{Ag}_{0.5}-\mathrm{Ho}_{\mathrm{x}}(\mathrm{x}=0,0.1,0,2.0,3,0,4$ and $0.5)$.

\begin{tabular}{llll}
\hline System wt. \% & $\begin{array}{l}\text { Young's } \\
\text { Modulus } \\
(\mathrm{GPa})\end{array}$ & $\begin{array}{l}\text { internal } \\
\text { Friction } \\
\left(\mathrm{Q}^{-1}\right)\end{array}$ & $\begin{array}{l}\text { Thermal } \\
\text { diffusivity } \\
\left(\mathrm{D}_{\text {th }}\right) * 10^{-8} \\
\left(\mathrm{~m}^{2} / \mathrm{s}\right)\end{array}$ \\
\hline $\mathrm{Bi}$ & 35.24 & 0.055 & 2.6869 \\
\hline $\mathrm{Bi}-\mathrm{Ag}_{0.5}$ & 55.62 & 0.102 & 2.4743 \\
\hline $\mathrm{Bi}-\mathrm{Ag}_{0.5}-\mathrm{Ho}_{0.1}$ & 53.14 & 0.035 & 2.1756 \\
\hline $\mathrm{Bi}-\mathrm{Ag}_{0.5}-\mathrm{Ho}_{0.2}$ & 56.55 & 0.041 & 3.6612 \\
\hline $\mathrm{Bi}-\mathrm{Ag}_{0.5}-\mathrm{Ho}_{0.3}$ & 60.89 & 0.026 & 4.0398 \\
\hline $\mathrm{Bi}-\mathrm{Ag}_{0.5}-\mathrm{Ho}_{0.4}$ & 68.93 & 0.019 & 4.5341 \\
\hline $\mathrm{Bi}-\mathrm{Ag}_{0.5}-\mathrm{Ho}_{0.5}$ & 74.01 & 0.014 & 10.988 \\
\hline
\end{tabular}

\subsubsection{Influence of $\mathrm{Ho}$ on $\mathrm{Hv}$ and creep resistance}

The mechanical properties of rapidly solidified alloys were determined by Vickers micro-hardness measurements. Using one applied constant load 10 gram-force $(0.0098 \mathrm{~N})$ to measure Vickers hardness values $(\mathrm{Hv})$ of all alloys. Depending on literature of preceding studies [32,33], can be calculated the values of hardness using the standard Vickers formula.

$$
\mathrm{Hv}=2 \frac{\mathrm{Fsin} \frac{136^{\circ}}{2}}{\mathrm{~d}^{2}} \approx 1.854 \frac{\mathrm{F}}{\mathrm{d}^{2}} \quad \text { approximatly }
$$


where $d$ the average diagonal, $F$ is the indentation force study (applied load), and 1.854 is a constant of a geometrical factor for the diamond pyramid. Table 5 gives the calculated values of Hv. Note from the table 5 that the value of $\mathrm{Hv}$ increased up to 235.94 at wt.0.5\% Ag, this is attributed to the presence of IMC such as $\mathrm{Ag}_{0.5} \mathrm{Bi}_{99.5}$, according to XRD analysis. Also, observed from XRD analysis is the absence of any new intermetallic compound after addition $\mathrm{Ho}$, but the values of $\mathrm{Hv}$ increases up to reach $254.61 \mathrm{GPa}$ at $0.5 \mathrm{wt} . \% \mathrm{Ho}$. This is may be attributed to the uniform distribution of Ho and IMC in Bi matrix ( as in SEM image), refinement the grain size, and cooling rate of rapid solidification technique [34]. measurement of Micro hardness indentation creep is one of the types of high-stress creep tests in which indentation deformation is a depended on dwell time of a load applied [35]. Improvements in creep properties in the Pb-free alloys are desired to avoid rupture. In this work and others [9], the variation of micro hardness (HV) with time at applying constant load $10 \mathrm{gf}(0.098 \mathrm{~N})$ was studied at room temperature for all solder alloys as shown in Fig 5 . The found from this Fig that $\mathrm{Hv}$ decreases by increasing dwell time. Also, observed that the $\mathrm{Bi}_{99}-\mathrm{Ag}_{0.5}-\mathrm{Ho}_{0.5}$ alloy has the highest hardness with time than that other alloys. The measurement of creep by Vickers micro_hardness test is called micro-creep. Fig 6 shown creep behavior of all solder Alloys. The region from $5 \mathrm{~s}$ to $90 \mathrm{~s}$ of curves of Fig 6 represents the secondary creep stage (steady-state creep), in which the creep tends to be semi-constant. The third stage doesn't occur, that refers to small loading value and time. The lower creep resistance of asquenched melt-spun alloy $\mathrm{Bi}-0.5 \mathrm{wt} . \% \mathrm{Ag}$ may be due to existence the high concentration of vacancies obtained by rapid solidification [9]. The $\mathrm{Bi}_{99}-\mathrm{Ag}_{0.5}-\mathrm{Ho}_{0.5}$ alloy has the highest creep resistance. In general, the solder alloys containing Ho have higher creep resistance than alloy without Ho. This is due to the fine structure and uniform distribution of Ho and IMC in Bi matrix as a result of rapid solidification. So we can say that the small addition of rare earth $(\mathrm{Ho})$ has led to an improvement in mechanical properties, and this is agreement with the results received in other studies [25,36-38].

Table 5. Vickers microhardness (Hv) of all prepared alloys.

\begin{tabular}{ll}
\hline Solder & $\mathrm{Hv}(\mathrm{MPa})$ \\
\hline $\mathrm{Bi}$ & 118.34 \\
\hline $\mathrm{Bi}_{99.5}-\mathrm{Ag}_{0.5}$ & 235.94 \\
\hline $\mathrm{Bi}_{99.4}-\mathrm{Ag}_{0.5}-\mathrm{Ho}_{0.1}$ & 224.23 \\
\hline $\mathrm{Bi}_{99.3}-\mathrm{Ag}_{0.5}-\mathrm{Ho}_{0.2}$ & 196.11 \\
\hline $\mathrm{Bi}_{99.2}-\mathrm{Ag}_{0.5}-\mathrm{Ho}_{0.3}$ & 228.44 \\
\hline $\mathrm{Bi}_{99.1}-\mathrm{Ag}_{0.5}-\mathrm{Ho}_{0.4}$ & 239.82 \\
\hline $\mathrm{Bi}_{99}-\mathrm{Ag}_{0.5}-\mathrm{Ho}_{0.5}$ & 254.61 \\
\hline
\end{tabular}




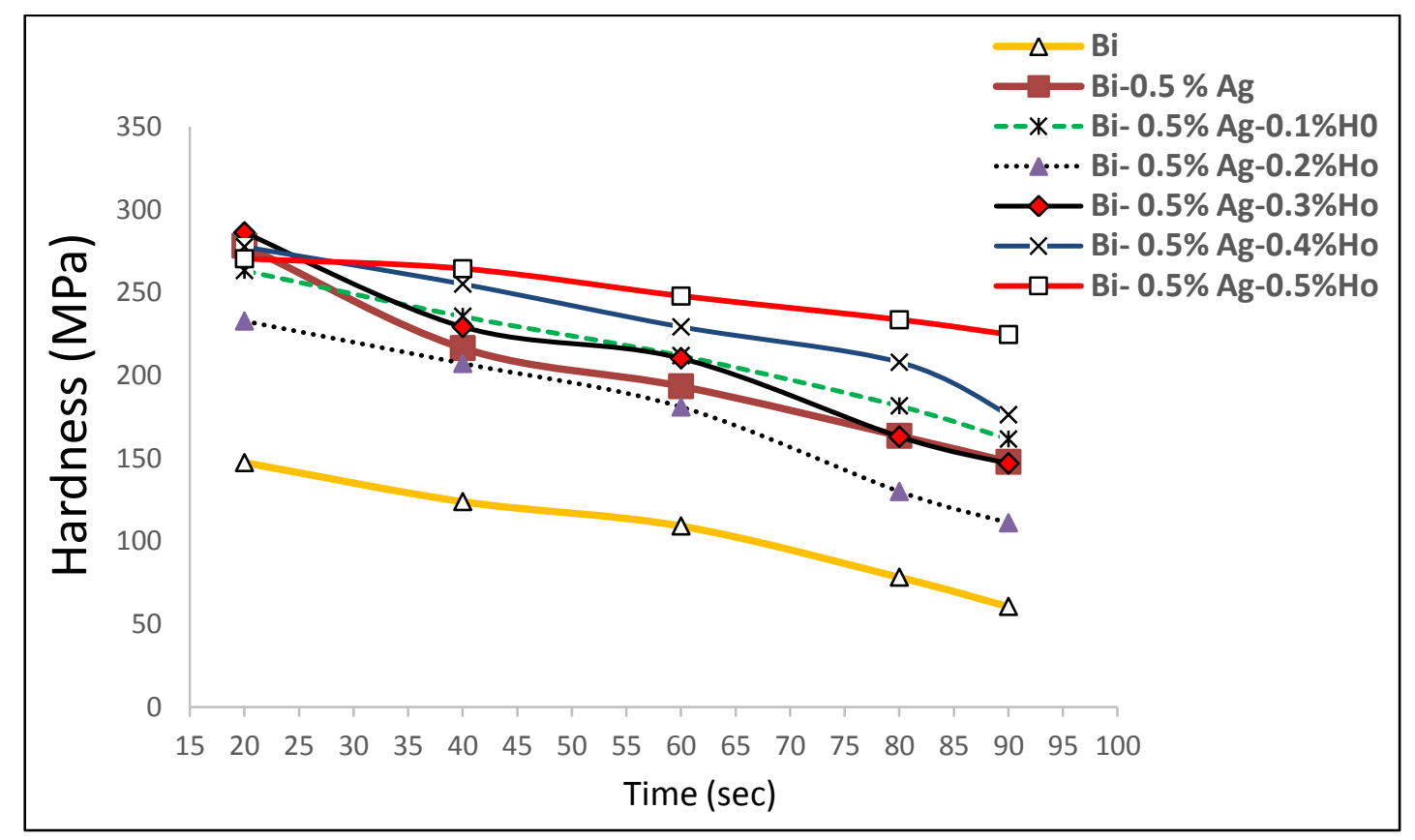

Fig.5. Variation of $\mathrm{Hv}$ with dwell time.

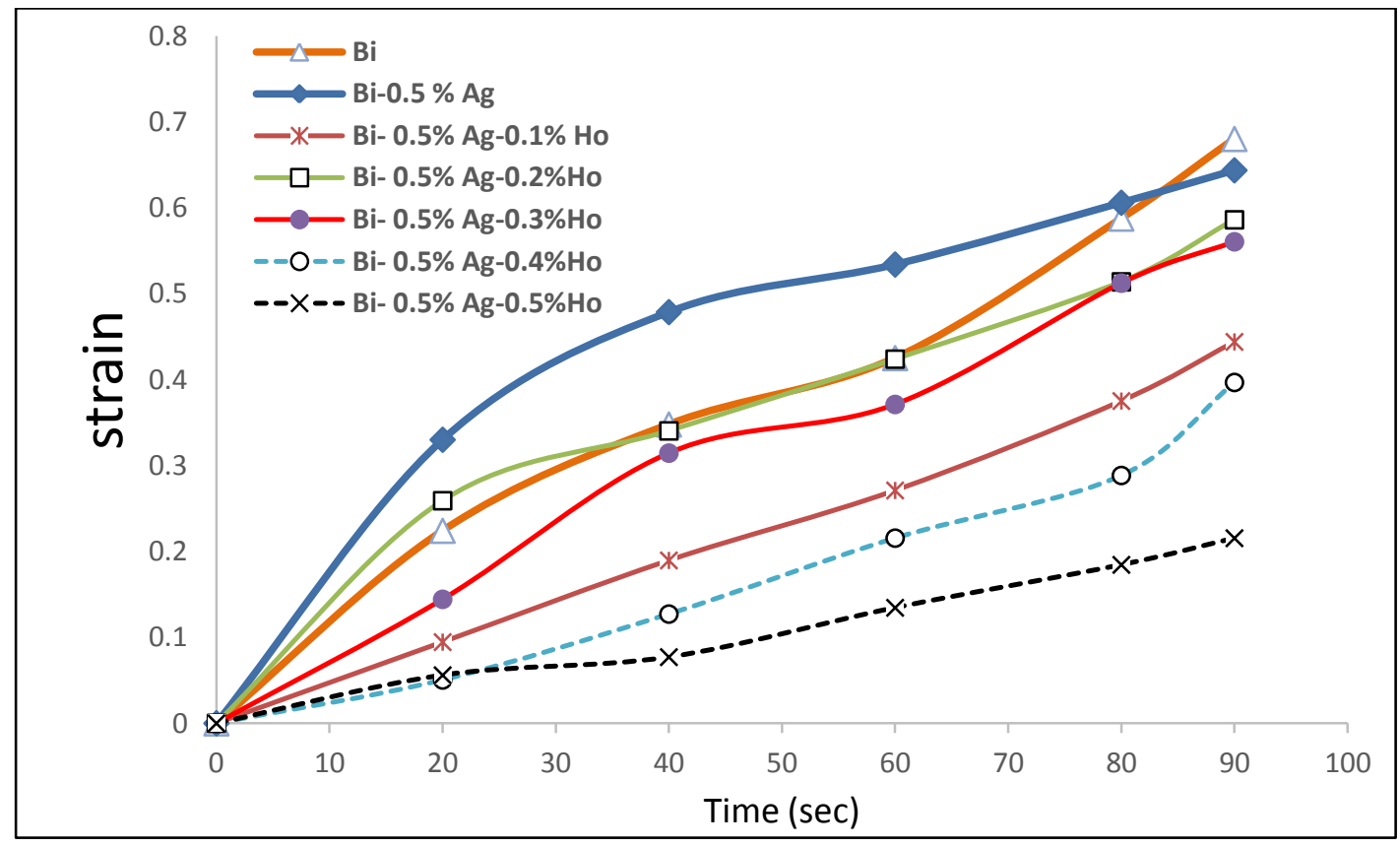

Fig.6. The creep behavior of as-quenched melt-spun alloys

\subsection{Influence of Ho on the electrical resistance}

The solder alloys are used in electronic packaging to order electrical interconnection between the parts of electrical appliances. Therefore, the solder joints must provide good electrical connections between those parts in electronic packaging, in order not to affect the functionality of the electrical circuits. In this part, we shall be concerned with understanding some of the electrical properties of Bi-Ag-Ho quenched ribbons. Often, the electrical conductivity is measured by a measure of electrical resistance. Table 6 shown values of electrical resistance measured at room temperature. The addition of $\mathrm{Ag}$ to $\mathrm{Bi}$ is expected to reduce the value of electrical resistivity because of the good electrical conductivity of $\mathrm{Ag}$. This may be due to freezes vacancies as a result of the rapid solidification process from melt. These vacancies playing a role as scattering centers for the conduction electrons, leading to increased electrical resistance. From this Table, it is found that the small 
additions of Ho give a great enhancement on the electrical conductivity of the Bi-Ag solder alloy, with adding $0.5 \mathrm{wt}$.\% Ho to Bi-0.5Ag produced a reduction in electrical resistivity by $73 \%$ (from $5.617 \mu \Omega$. $\mathrm{m}$ to $1.54 \mu \Omega$. $\mathrm{m}$ ) compared to Bi pure. This is may be attributed to reducing the particle size (according to XRD analysis) and uniform distribution of Holmium and IMC in Bi matrix (according to SEM image). Fig 7 presents increased of the electrical resistivity with increases temperature depending on depending on the alloy composition. Where we are found that the $\mathrm{Bi}_{9 g} \mathrm{Ag}_{0.5} \mathrm{Ho}_{0.5}$ solder alloy has the highest electrical stability at elevated temperatures compared to other solder alloys, due to may be that the rise of the specific heat. This electrical behavior alongside with the good mechanical and acceptable thermal properties make this alloy more reliable and desirable for soldering applications and electronic assembly.

Table 6. Electrical resistivity of all prepared lead-free solders at room temperature.

\begin{tabular}{ll}
\hline Solder & Resistivity $(\mu \Omega . \mathrm{m})$ \\
\hline $\mathrm{Bi}$ & 5.617 \\
\hline $\mathrm{Bi}_{99.5}-\mathrm{Ag}_{0.5}$ & 7.789 \\
\hline $\mathrm{Bi}_{99.4}-\mathrm{Ag}_{0.5}-\mathrm{Ho}_{0.1}$ & 7.308 \\
\hline $\mathrm{Bi}_{99.3}-\mathrm{Ag}_{0.5}-\mathrm{Ho}_{0.2}$ & 4.959 \\
\hline $\mathrm{Bi}_{99.2}-\mathrm{Ag}_{0.5}-\mathrm{Ho}_{0.3}$ & 5.166 \\
\hline $\mathrm{Bi}_{9.1}-\mathrm{Ag}_{0.5}-\mathrm{Ho}_{0.4}$ & 3.352 \\
\hline $\mathrm{Bi}_{99}-\mathrm{Ag}_{0.5}-\mathrm{Ho}_{0.5}$ & 1.54 \\
\hline
\end{tabular}

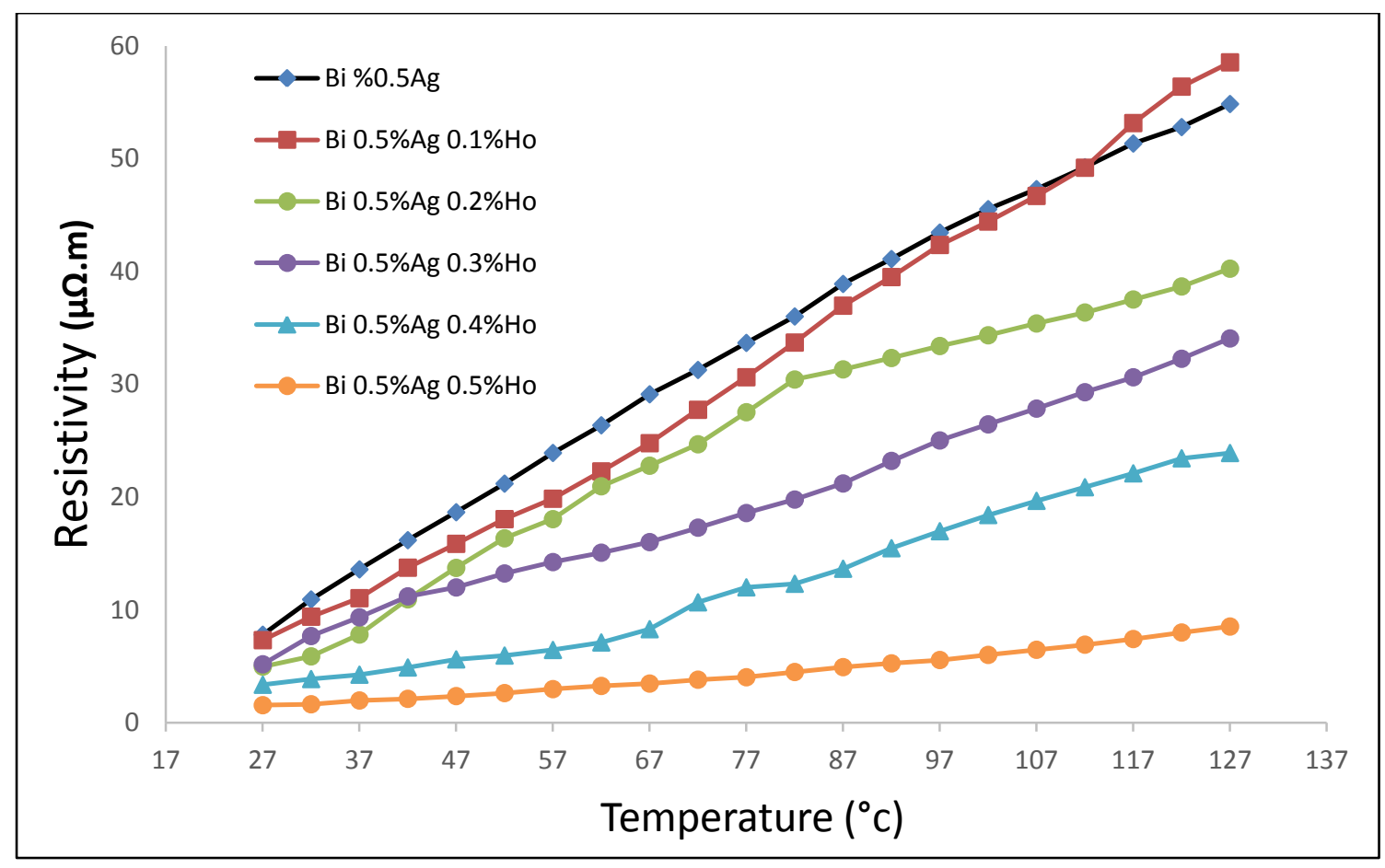

Fig.7. Electrical resistivity as a function of temperature of all prepared solders. 


\section{Conclusion}

In this study, binary and ternary lead-free solder alloys in the form of ribbons were manufactured by rapid solidification method using melt-spun technique. In order to, that the Bi-Ag solder possess a better potential as a replacement for lead $(\mathrm{Pb})$ solders, the mechanical, thermal and electrical behaviors were improved by structural modified of solder alloys as result of adding small quantities of rare earth $(\mathrm{Ho})$ and rapid solidification from melt. The main results are summarized as follows.

1- Adding $0.5 \mathrm{wt} . \% \mathrm{Ag}$ to Bi led to raising (around 99\%) of hardness, due to the formation IMC, because that the $\mathrm{Ag}$ tends to interact more with $\mathrm{Bi}$. But the melting point $\left(\mathrm{T}_{\mathrm{m}}\right)$ decreased by $3.6^{\circ} \mathrm{C}$, also the creep rate increased, this is attributed to increasing both the size of IMC and concentration of freezing of vacancies result by of rapid solidification

2- The addition of minimal rare earth elements $(\mathrm{Ho})$ makes the IMCs finer and more uniform distribution in the Bi matrix. at $0.5 \mathrm{wt} . \%$ Ho increase occured in both, Young's modulus by $33 \%$ ( from $55.62 \mathrm{GPa}$ to 74.01 $\mathrm{GPa}$ ), hardness value by $8 \%$ ( from $235.94 \mathrm{MPa}$ to $254.61 \mathrm{MPa}$ ), and resistance of creep compared to the $\mathrm{Bi}-0.5 \mathrm{Ag}$. It is also, found that the small additions of Ho have no obvious effect on the melting temperature $\left(\mathrm{T}_{\mathrm{m}}\right)$, but the pasty range (mushy zone) decreased from $13.98^{\circ} \mathrm{C}$ to $11.432{ }^{\circ} \mathrm{C}$ at $0.5 \mathrm{wt} . \%$ of Ho. The results also showed that the electrical resistivity decreases by about $80 \%$ at $0.5 \mathrm{wt} . \%$ Ho compared with $\mathrm{Bi}-0.5 \mathrm{Ag}$, those improvements are related to the structural changes of these alloys. this also indicates a decrease in the concentration of vacancies as a result of the rapid solidification and that playing a role as scattering centers of the conduction electrons. Also, we are found that the $\mathrm{Bi}_{99}-\mathrm{Ag}_{0.5}-\mathrm{Ho}_{0.5}$ solder alloy has the highest electrical stability at elevated temperatures, due to may be that the rise of the specific heat. From the above, we can say that the $\mathrm{Bi}_{99}-\mathrm{Ag}_{0.5}-\mathrm{Ho}_{0.5}$ is a candidate alloy for lead-free solder for hightemperature applications.

\section{References}

[1] N. Kang, H.S. Na, S.J. Kim, C.Y. Kang, Alloy design of Zn-Al-Cu solder for ultra high temperatures, J. Alloys Compd. 467 (2009) 246-250. doi:10.1016/j.jallcom.2007.12.048.

[2] D. Manasijević, D. Minić, D. Živković, I. Katayama, J. Vřeštál, D. Petković, Experimental investigation and thermodynamic calculation of the Bi-Ga-Sn phase equilibria, J. Phys. Chem. Solids. 70 (2009) 12671273. doi:10.1016/j.jpcs.2009.07.010.

[3] D. Minić, M. Premović, D. Manasijević, V. Ćosović, D. Živković, A. Marković, Experimental investigation and thermodynamic calculations of the Ag-Bi-Ga phase diagram, J. Alloys Compd. 646 (2015) 461-471. doi:10.1016/j.jallcom.2015.05.163.

[4] T.L. Guidotti, L. Ragain, Protecting Children from Toxic Exposure: Three Strategies, Pediatr. Clin. North Am. 54 (2007) 227-235. doi:10.1016/j.pcl.2007.02.002.

[5] F. Barbosa, J.E. Tanus-Santos, R.F. Gerlach, P.J. Parsons, A Critical Review of Biomarkers Used for Monitoring Human Exposure to Lead: Advantages, Limitations, and Future Needs, Environ. Health Perspect. 113 (2005) 1669-1674. doi:10.1289/ehp.7917.

[6] Rohaizuan.Rosilli, Azmah.Hanim, Mohamed.Ariff, Bi-Ag as an Alternative High Temperature Solder, J. Sci. \& Technol. 22 (2014) 1-13.

[7] J. Shen, Y. Liu, H. Gao, Abnormal growth of Ag3Sn intermetallic compounds in Sn-Ag lead-free solder, Chinese Sci. Bull. 51 (2006) 1766-1770. doi:10.1007/s11434-006-2043-y.

[8] C. European Parliament, Directive 2002/95/ec of the European Parliament and of the Council of 27 January 2003 on the restriction of the use of certain hazardous substances in electrical and electronic equipment, Off. J. Eur. Union. L 037 (2003) 19-23. doi:10.1016/j.jclepro.2010.02.014. 
[9] R.M. Shalaby, Effect of rapid solidification on mechanical properties of a lead free Sn-3.5Ag solder, J. Alloys Compd. 505 (2010) 113-117. doi:10.1016/j.jallcom.2010.05.179.

[10] R.M. Shalaby, Influence of indium addition on structure, mechanical, thermal and electrical properties of tin-antimony based metallic alloys quenched from melt, J. Alloys Compd. 480 (2009) 334-339. doi:10.1016/j.jallcom.2009.02.013.

[11] R.M. Shalaby, Effect of silver and indium addition on mechanical properties and indentation creep behavior of rapidly solidified Bi-Sn based lead-free solder alloys, Mater. Sci. Eng. A. 560 (2013) 86-95.

[12] R.M. Shalaby, A.S. Waqlan, M. Kamal, Enhancement of mechanical properties of melt-spun process Al$\mathrm{Li}$ based metallic alloys for aerospace applications, International Journal of Nano and Material Sciences. 7 (2018) 1-15.

[13] R.M. Shalaby, N.A. Abdelhakim, M. Kamal, Effect of rapid solidification on mechanical properties of free machining lead free Aluminum alloys for improved machinability, J. Adv. Physic. 13 (2007) 5155-5166.

[14] R.M. Shalaby, M.S. Gumaan, E.A.M. Ali, M. Kamal, Copper effects in mechanical, thermal and electrical properties of rapidly solidified eutectic Sn-Ag alloy, J. Materials in Electronics. 0 (2018) 0. doi:10.1007/s10854-018-8906-6.

[15] T. El-Ashram, R.M. Shalaby, Effect of rapid solidification and small additions of $\mathrm{Zn}$ and $\mathrm{Bi}$ on the structure and properties of Sn-Cu eutectic alloy, J. Electron. Mater. 34 (2005) 212-215. http://link.springer.com/10.1007/s11664-005-0234-y.

[16] J. Song, H. Chuang, Z. Wu, Interfacial reactions between Bi-Ag High-Temperature Solders and Metallic Substrates, J. Electron. Mater. 35 (2006) 1041-1049.

[17] Y. Shi, W. Fang, Z. Xia, Y. Lei, F. Guo, X. Li, Investigation of rare earth-doped BiAg high-temperature solders, J. Mater. Sci. Mater. Electron. 21 (2010) 875-881. doi:10.1007/s10854-009-0010-5.

[18] M. Rettenmayr, P. Lambracht, B. Kempf, C. Tschudin, Zn-Al Based Alloys as Pb-Free Solders for Die Attach, J. Electron. Mater. 31 (2002) 2-9.

[19] W. Dong, Y. Shi, Z. Xia, Y. Lei, F. Guo, Effects of trace amounts of rare earth additions on microstructure and properties of Sn-Bi-based solder alloy, J. Electron. Mater. 37 (2008) 982-991. doi:10.1007/s11664008-0458-8.

[20] J.N. Lalena, N.F. Dean, M.W. Weiser, Experimental investigation of Ge-Doped Bi-11Ag as a new Pb-free solder alloy for power die attachment, J. Electron. Mater. 31 (2002) 1244-1249. doi:10.1007/s11664002-0016-8.

[21] B. Li, Y. Shi, Y. Lei, F. Guo, Z. Xia, B. Zong, Effect of rare earth element addition on the microstructure of Sn-Ag-Cu solder joint, J. Electron. Mater. 34 (2005) 217-224. doi:10.1007/s11664-005-0207-1.

[22] Z. Chen, Y. Shi, Z. Xia, Constitutive relations on creep for SnAgCuRE lead-free solder joints, J. Electron. Mater. 33 (2004) 964-971. doi:10.1007/s11664-004-0023-z.

[23] Z. Chen, Y. Shi, Z. Xia, Y. Yan, Properties of lead-free solder SnAgCu containing minute amounts of rare earth, J. Electron. Mater. 32 (2003) 235-243. doi:10.1007/s11664-003-0215-y.

[24] Z.G. Chen, Y.W. Shi, Z.D. Xia, Y.F. Yan, Study on the microstructure of a novel lead-free solder alloy SnAgCu-RE and its soldered joints, J. Electron. Mater. 31 (2002) 1122-1128. doi:10.1007/s11664-0020052-4.

[25] Y. Shi, J. Tian, H. Hao, Z. Xia, Y. Lei, F. Guo, Effects of small amount addition of rare earth Er on 
microstructure and property of SnAgCu solder, J. Alloys Compd. 453 (2008) 180-184. doi:10.1016/j.jallcom.2006.11.165.

[26] R.M. Shalaby, A.S. Waqlan, M. Kamal, Influence of rapid solidification and lithium additions on microstructure and mechanical properties of aluminum based alloys, J. Adv. Phys. Vol 12 (2016) 4440 4450 .

[27] R.M.Shalaby, Wettability and electrical properties of Bi-Sn based lead free solders alloys, Int. J. Phys. Res. 3 (2013) 1-6.

[28] Y.K. Wu, K.L. Lin, B. Salam, Specific heat capacities of Sn-Zn-based solders and Sn-Ag-Cu solders measured using differential scanning calorimetry, J. Electron. Mater. 38 (2009) 227-230. doi:10.1007/s11664-008-0589-y.

[29] A. Inoue, H.S. Chen, J.T. Krause, T. Masumoto, M. Hagiwara, Young's modulus of Fe-, Co-, Pd- and Ptbased amorphous wires produced by the in-rotating-water spinning method, J. Mater. Sci. 18 (1983) 2743-2751. doi:10.1007/BF00547591.

[30] E. Screiber, O.L. Anderson, N. Soga, Elastic constants and their measurements, J. McGrawHill, New York. (1973).

[31] R.M. Shalaby, M. Kamal, A.-B. El-Bediwi, M. Younus, Correlation between microstructure, mechanical and thermal properties of In-Bi-Sn-Ag melt spun alloys, J. Adv. Chem. 10 (2014) 2146-2161. doi:10.13140/RG.2.1.3973.9042.

[32] M. Yan, W.. Zhu, B. Cantor, The microstructure of as-melt spun Al-7\%Si-0.3\%Mg alloy and its variation in continuous heat treatment, Mater. Sci. Eng. A. 284 (2000) 77-83. doi:10.1016/S0921-5093(00)007917.

[33] O. Uzun, T. Karaaslan, M. Gogebakan, M. Keskin, Hardness and microstructural characteristics of rapidly solidified Al-8-16 wt.\%Si alloys, J. Alloys Compd. 376 (2004) 149-157. doi:10.1016/j.jallcom.2004.01.017.

[34] M. Kamal, R.M. Shalaby, Effect of reactive metal on creep resistance of Sn-50Bi lead free solder alloys, Int. J. Phys. Res. 4 (2014) 19-28.

[35] R. Roumina, B. Raeisinia, R. Mahmudi, Room temperature indentation creep of cast Pb-Sb alloys, Scr. Mater. 51 (2004) 497-502. doi:10.1016/j.scriptamat.2004.05.048.

[36] D. Wenwen, S. Yangshan, M. Xuegang, X. Feng, Z. Min, W. Dengyun, Microstructure and mechanical properties of Mg-Al based alloy with calcium and rare earth additions, Mater. Sci. Eng. A. 356 (2003) 17. doi:10.1016/S0921-5093(02)00551-8.

[37] D.Q. Yu, J. Zhao, L. Wang, Improvement on the microstructure stability, mechanical and wetting properties of Sn-Ag-Cu lead-free solder with the addition of rare earth elements, J. Alloys Compd. 376 (2004) 170-175. doi:10.1016/j.jallcom.2004.01.012.

[38] C.M.L. Wu, D.Q. Yu, C.M.T. Law, L. Wang, Properties of lead-free solder alloys with rare earth element additions, Mater. Sci. Eng. 44 (2004) 1-44. 